\title{
Resolution of Biphasic Binding of the Opioid Antagonist Naltrexone in Brain Membranes
}

\author{
Ann E. Remmers and Fedor Medzihradsky \\ Departments of Biological Chemistry and Pharmacology, University of Michigan \\ Medical School, Ann Arbor, Michigan, U.S.A.
}

\begin{abstract}
In synaptosomal membranes from rat brain cortex, in the presence of $150 \mathrm{mM} \mathrm{NaCl}$, the opioid antagonist $\left[{ }^{3} \mathrm{H}\right]$ naltrexone bound to two populations of receptor sites with affinities of 0.27 and $4.3 \mathrm{n} M$, respectively. Guanosine5'-(3-thiotriphosphate) had little modulating effect and did not alter the biphasic nature of ligand binding. On the other hand, receptor-selective opioids differentially inhibited the two binding components of $\left[{ }^{3} \mathrm{H}\right]$ naltrexone. As shown by nonlinear least-squares analysis, the $\mu$ opioids Tyr-D-AlaGly-(Me)Phe-Gly-ol or sufentanil abolished high-affinity $\left[{ }^{3} \mathrm{H}\right]$ naltrexone binding, whereas the $\delta$-selective ligands [D$\mathrm{Pen}^{2}$,D-Pen ${ }^{5}$ ]enkephalin, ICI 174,864, and oxymorphindole
\end{abstract}

inhibited and eventually eliminated the low-affinity component in a concentration-dependent manner. These results indicate that, in contrast to the guanine nucleotide-sensitive biphasic binding of opioid-alkaloid agonists, the heterogeneity of naltrexone binding in brain membranes reflects ligand interaction with different opioid-receptor types. Key Words: Opioid receptors-Agonist-antagonist binding $-\mu$ - and $\delta$-selective opioids- $\left[{ }^{3} \mathrm{H}\right]$ Naltrexone-Rat brain cortex. Remmers A. E. and Medzihradsky F. Resolution of biphasic binding of the opioid antagonist naltrexone in brain membranes. J. Neurochem. 57, 1265-1269 (1991).
In interacting with their receptors, opioid alkaloids, both agonists and antagonists, display characteristic biphasic binding. In rat brain membranes, high- and low-affinity binding components were described for the agonists dihydromorphine (Childers and Snyder, 1980), sufentanil (Leysen et al., 1983), and etorphine (Fischel and Medzihradsky, 1986), and for the antagonists naloxone (Childers and Snyder, 1980) and naltrexone (Fischel and Medzihradsky, 1981). Heterogeneity in the dissociation of bound $\left[{ }^{3} \mathrm{H}\right]$ naltrexone (Fischel and Medzihradsky, 1981) and $\left[{ }^{3} \mathrm{H}\right]$ naloxone (Szücs et al., 1987) has also been reported. After various interpretations of these findings, it was recently shown that the biphasic binding of $\left[{ }^{3} \mathrm{H}\right]$ dihydromorphine, but not $\left[{ }^{3} \mathrm{H}\right]$ naltrexone, reflects different association states of the agonist-occupied opioid receptor with $G$ protein (Remmers and Medzihradsky, 1991). Considering the results of the latter study, which included evidence for lacking modulation of antagonist binding by guanine nucleotides also described previously (e.g., Blume, 1978), we have in this work investigated the interaction of $\left[{ }^{3} \mathrm{H}\right]$ naltrexone with multiple opioid receptors as the underlying mechanism for the heterogeneity of its receptor binding. Initially, we have identified highly selective $\mu$ and $\delta$ opioids suitable to resolve ligand binding to multiple opioid receptors (Clark et al., 1988). The obtained results indicate that, in synaptosomal membranes from rat brain cortex, the biphasic binding of $\left[{ }^{3} \mathrm{H}\right]$ naltrexone reflects its interaction with both $\mu$-and $\delta$-opioid receptors.

\section{MATERIALS AND METHODS}

\section{Materials}

$\left[{ }^{3} \mathrm{H}\right]$ Naltrexone was kindly provided by the National Institute on Drug Abuse. Tyr-D-Ala-Gly-(Me)Phe-Gly-ol (DAMGO) was purchased from Peninsula Laboratories and guanosine-S'-(3-thiotriphosphate)-tetralithium salt (GTP- $\gamma$ S) from Boehringer-Mannheim Biochemicals. The $\mu$ - and $\delta$ selective opioids sufentanil, DAMGO, [D-Pen $\left.{ }^{2}, \mathrm{D}-\mathrm{Pen}^{5}\right]-$ enkephalin (DPDPE), ICI 174,864 (Clark et al., 1988), and oxymorphindole (Woods et al., 1990) were obtained through the Opioid Basic Research Center at the University of Michigan.
Received February 19, 1991; accepted March 7, 1991

Address correspondence and reprint requests to Dr. F. Medzihradsky at Department of Biological Chemistry, University of Michigan Medical School, Ann Arbor, MI 48109-0606, U.S.A.
Abbreviations used: DADLE, [D-Ala ${ }^{2}, \mathrm{D}-\mathrm{Leu}^{5}$ ]enkephalin; DAMGO, Tyr-D-Ala-Gly-(Me)Phe-Gly-ol; DPDPE, [D-Pen ${ }^{2}, \mathrm{D}-$ Pen ${ }^{5}$ enkephalin; GTP- $\gamma$-S, guanosine-5'-(3-thiotriphosphate) ICI 174,864 ,(allyl) ${ }_{2}$-Tyr-Aib-Aib-Phe-Leu-OH. 


\section{Membrane preparation}

Synaptosomal membranes from brain cortices of adult male Sprague-Dawley rats were prepared as described previously (Cahill and Medzihradsky, 1976). Aliquots of the membrane suspension, at a protein concentration of $1 \mathrm{mg} /$ $\mathrm{ml}$, were stored at $-70^{\circ} \mathrm{C}$. Protein was determined according to Bradford (1976), using bovine serum albumin as the standard.

\section{Opioid-receptor binding}

Equilibrium binding of $\left[{ }^{3} \mathrm{H}\right]$ naltrexone was reached in 30 min, and was performed at $25^{\circ} \mathrm{C}$ as described previously (Fischel and Medzihradsky, 1981). The assay medium consisted of $400 \mu \mathrm{l}$ of membrane suspension in $50 \mathrm{mM}$ Tris$\mathrm{HCl}, \mathrm{pH} 7.4,50 \mu \mathrm{l}$ of $\mathrm{NaCl}$ to give a final concentration of $150 \mathrm{mM}, 50 \mu \mathrm{l}$ of a solution of unlabeled opioid, and $25 \mu \mathrm{l}$ of $\left[{ }^{3} \mathrm{H}\right]$ naltrexone solution. Specific ligand binding was defined as the difference between $\left[{ }^{3} \mathrm{H}\right]$ naltrexone bound in the absence and presence of $1 \mu M$ unlabeled naltrexone. In some experiments, $5 \mu M$ GTP- $\gamma-S$ was included in the assay medium. In all experiments with competing opioids, the membranes were first incubated for $15 \mathrm{~min}$ at $25^{\circ} \mathrm{C}$ with the unlabeled ligand and $150 \mathrm{mM} \mathrm{NaCl}$, followed by the incubation with $\left[{ }^{3} \mathrm{H}\right]$ naltrexone to reach equilibrium.

\section{Data analysis}

For the statistical evaluation of ligand binding, the NONLIN module in the computer program SYSTAT was used as described (Remmers et al., 1990). This generalized nonlinear least-squares regression program was applied to fit the data to a two- or one-site binding model. After the initial regression, the residuals were displayed in a normal probability plot, using the GRAPH module of SYSTAT, to evaluate both their magnitude and departure from expected normally distributed residuals. All data reported are based on regressions for which the distribution of residuals was not different from a normal distribution. The corresponding standard error of the mean (SEM) was computed within NONLIN from the residual sum of squares (RSS) of the regression.

\section{RESULTS}

Scatchard analysis of $\left[{ }^{3} \mathrm{H}\right]$ naltrexone binding in the presence of $150 \mathrm{mM} \mathrm{NaCl}$ revealed two populations of saturable binding sites with $K_{\mathrm{D}} \mathrm{s}$ of 0.27 and $4.3 \mathrm{n} M$, respectively. In contrast to the strong modulation of opioid-agonist binding by guanine nucleotides (Blume, 1978; Childers and Snyder, 1980; Remmers and Medzihradsky, 1991), GTP- $\gamma$-S did not alter the binding of $\left[{ }^{3} \mathrm{H}\right]$ naltrexone (Fig. 1, inset).

To test the hypothesis that high- and low-affinity naltrexone binding reflect interaction of the antagonist with the $\mu$ - and $\delta$-opioid receptor, respectively, the displacement of 0.5 and $10 \mathrm{nM}\left[{ }^{3} \mathrm{H}\right]$ naltrexone (to saturate the low-affinity binding sites) by different concentrations of $\mu$ - and $\delta$-selective opioids was performed. We have previously shown that the $\mu / \delta$ selectivity indices (ratio of $\mathrm{EC}_{50} \mathrm{~S}$ in displacing tritiated DAMGO and DPDPE, respectively) for DPDPE, ICI 174,864, and oxymorphindole were 1,200, 998 (Clark et al., 1988), and 320 (Woods et al., 1990), respectively, whereas for

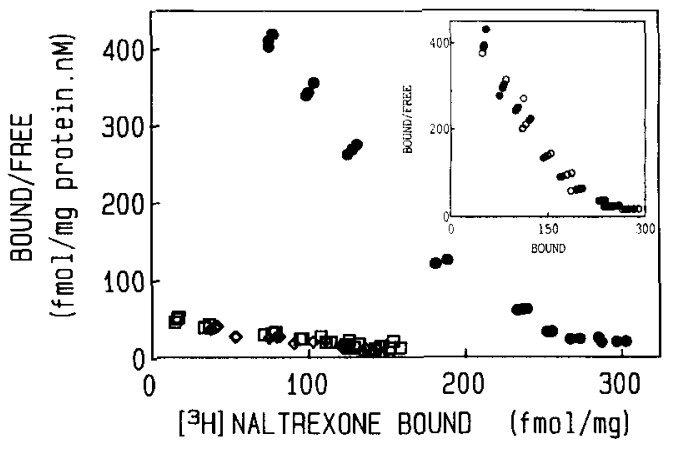

FIG. 1. Scatchard plots of $\left[{ }^{3} \mathrm{H}\right]$ naltrexone binding in the absence and presence of GTP- $\gamma$-S and of $\mu$-selective opioids. Equilibrium binding of $\left[{ }^{3} \mathrm{H}\right]$ naltrexone was performed in synaptosomal membranes in the presence of $150 \mathrm{mM} \mathrm{NaCl}$ and in the absence () and presence of $25 \mathrm{n} M$ sufentanil ( $)$ ) or $1 \mu M$ DAMGO ( $\square$ ). Plotted are results from representative experiments replicated at least three times. The corresponding binding parameters and statistical information are listed in Table 1 . Shown in the inset is the binding of $\left[{ }^{3} \mathrm{H}\right]$ naltrexone in the absence $(\Theta)$ and presence (O) of $5 \mu M$ GTP- $\gamma-\mathrm{S}$, both in the presence of $150 \mathrm{mM} \mathrm{NaCl}$. The respective binding constants without and with (in parentheses) GTP $\gamma$-S were as follows: $K_{\mathrm{D}_{1}}, 0.36(0.38) \mathrm{n} M, K_{\mathrm{D}_{2}}, 5.8(6.0) \mathrm{n} M, B_{\max _{1}}, 177(177)$ $\mathrm{fmol} / \mathrm{mg}$ of protein, and $B_{\max _{2}}, 135(149) \mathrm{fmol} / \mathrm{mg}$ of protein. These values represent the mean of 82 individual data points obtained in three experiments.

DAMGO and sufentanil, they were 0.02 and 0.03 (Clark et al., 1988). The high binding selectivities of DAMGO, sufentanil, and DPDPE were also described by the approach of site-directed alkylation of opioid receptors (James and Goldstein, 1984). The interaction between naltrexone and $\kappa$ receptors in the membrane preparation used was marginal: residual binding of 10 $\mathrm{n} M\left[{ }^{3} \mathrm{H}\right]$ naltrexone in the presence of sufentanil and oxymorphindole represented $4 \%$ of total binding. Furthermore, the $\kappa$-selective opioid agonist U69,593 inhibited the binding of $0.5 \mathrm{n} M\left[{ }^{3} \mathrm{H}\right]$ naltrexone in the presence of $150 \mathrm{mM} \mathrm{NaCl}$ with an $\mathrm{EC}_{50}$ of $>10 \mu M$. Previously, the limited density of sites labeled by $\left[{ }^{3} \mathrm{H}\right] \mathrm{U} 69,583$ has prevented the use of rat brain membranes to investigate the interaction of opioids with $\kappa$ receptors in routine assays (Clark et al., 1988). Thus, based on the binding selectivity and on initial displacement experiments, $50 \mathrm{n} M$ oxymorphindole, $2 \mu M$ DPDPE, or $2 \mu M$ ICI 174,864 were selected to inhibit the low-affinity, putative $\delta$ binding of $\left[{ }^{3} \mathrm{H}\right]$ naltrexone. On the other hand, $25 \mathrm{n} M$ sufentanil and $1 \mu M$ DAMGO were chosen to block the high-affinity, putative $\mu$ component of the antagonist.

In contrast to the remarkably similar biphasic binding in the absence and presence of GTP- $\gamma$-S (Fig. 1, inset), nonlinear least-squares analysis of $\left[{ }^{3} \mathrm{H}\right]$ naltrexone binding in the presence of competing $\mu$ or $\delta$ ligands revealed a single population of binding sites. In the presence of $\mu$ opioids, the high-affinity $\left[{ }^{3} \mathrm{H}\right]$ naltrexone component was abolished and the $K_{\mathrm{D}}$ of remaining binding sites was not significantly different from that displayed by low-affinity antagonist binding 
TABLE 1. Parameters of $l^{3}$ HJnaltrexone binding

\begin{tabular}{|c|c|c|c|c|c|}
\hline \multirow[b]{3}{*}{$\begin{array}{c}\text { Competing } \\
\text { ligand }\end{array}$} & \multicolumn{5}{|c|}{ Binding parameters } \\
\hline & $K_{\mathrm{D}_{1}}$ & $K_{\mathrm{D}_{2}}$ & $B_{\max }$ & $B_{\max 2}$ & \\
\hline & \multicolumn{2}{|c|}{$(\mathrm{n} M)$} & \multicolumn{2}{|c|}{$\begin{array}{l}\text { (fmol } / \mathrm{mg} \text { of } \\
\text { protein) }\end{array}$} & $\mathrm{n}$ \\
\hline None & $0.26(0.03)$ & $4.3(1.1)$ & $180(15)$ & $156(23)$ & 70 \\
\hline DAMGO & & & & & \\
\hline$(1 \mu M)$ & ND & $4.4(0.2)$ & ND & $194(6)$ & 59 \\
\hline $\begin{array}{l}\text { Sufentanil } \\
\qquad(25 \mathrm{nM})\end{array}$ & ND & $4.4(0.6)$ & ND & $192(24)$ & 57 \\
\hline ICI 174,864 & & & & & \\
\hline$(2 \mu M)$ & $0.50(0.02)^{a}$ & ND & $197(4)$ & ND & 60 \\
\hline$(10 \mu M)$ & $0.73(0.02)^{a}$ & ND & $236(3)^{a}$ & ND & 50 \\
\hline$(25 \mu M)$ & $1.27(0.07)^{a}$ & ND & $189(8)$ & ND & 51 \\
\hline DPDPE $(2 \mu M)$ & $0.77(0.02)^{a}$ & ND & $201(3)^{a}$ & ND & 57 \\
\hline $\begin{array}{l}\text { Oxymorphindole } \\
\quad(50 \mathrm{n} M)\end{array}$ & $0.55(0.17)^{a}$ & ND & $210(4)^{a}$ & ND & 62 \\
\hline
\end{tabular}

Equilibrium-binding experiments were performed in the presence of $150 \mathrm{~m} M \mathrm{NaCl}$. Results of at least three experiments, with a total of n observations, were pooled and fitted to one- and two-site binding models as described in Materials and Methods. Shown are the binding parameters (SEM in parentheses) that best fit the data as determined by the residual sum of squares. ND, not detectable.

${ }^{a}$ Values that are different from respective controls at the 5\% level of significance.

in the absence of inhibitors (Fig. 1 and Table 1). In contrast, selective $\delta$ opioids eliminated the low-affinity binding component of $\left[{ }^{3} \mathrm{H}\right]$ naltrexone (Figs. 2, 3; Table 1).

As illustrated for the displacement by ICI 174,864 (Fig. 3), the affinity of the remaining uninhibited binding component was dependent on the concentration of displacing opioid used: in the presence of 2 and 10 $\mu M$ ICI 174,864 , the $K_{\mathrm{D}}$ of $\left[{ }^{3} \mathrm{H}\right]$ naltrexone binding increased to 0.5 and $0.7 \mathrm{n} M$, respectively, from $0.3 \mathrm{n} M$ obtained in the absence of competing ligand (Table 1).

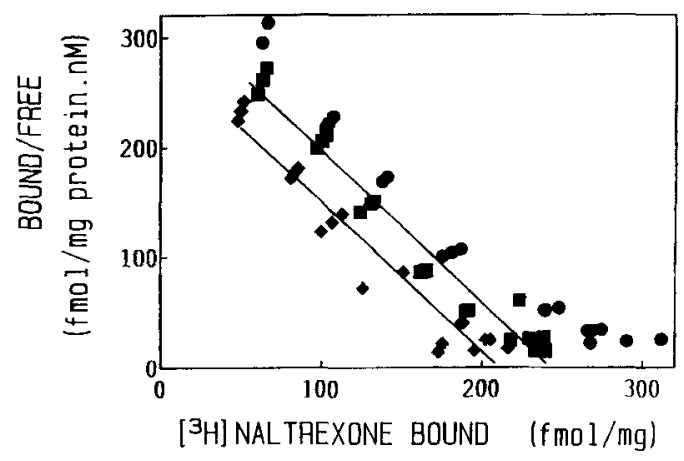

FIG. 2. Scatchard plots of $\left[{ }^{3} \mathrm{H}\right]$ naltrexone binding in the absence and presence of $\delta$-selective opioids. Equilibrium binding of $\left[{ }^{3} \mathrm{H}\right]$ naltrexone in synaptosomal membranes was performed in the presence of $150 \mathrm{mM} \mathrm{NaCl}$ and in the absence (๑) and presence of $50 \mathrm{nM}$ oxymorphindole ( $\square$ ) or $2 \mu M$ DPDPE $(\$)$. Shown are results of a representative experiment replicated three times. The corresponding binding parameters and statistical information are listed in Table 1.

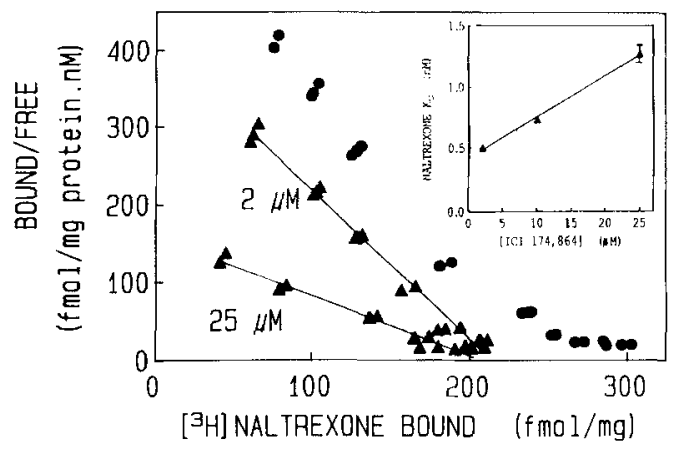

FIG. 3. Resolution of $\left[{ }^{3} \mathrm{H}\right]$ naltrexone binding by different concentrations of a $\delta$-selective opioid. Equilibrium binding of $\left[{ }^{3} \mathrm{H}\right]$ naltrexone in synaptosomal membranes was performed in the presence of $150 \mathrm{mM} \mathrm{NaCl}$ and in the absence (e) and presence (4) of $\mathrm{ICl}$ 174,864 at concentrations as indicated. Shown in the inset is the computed relationship between the $K_{\mathrm{D}}$ of $\left[{ }^{3} \mathrm{H}\right]$ naltrexone binding at the $\mu$ receptor and the added concentration of the $\delta$ opioid. The corresponding $K_{\mathrm{D}}$ values are listed in Table 1. Plotted are the results of representative experiments replicated three times.

Considering the interdependence of binding parameters in statistical analysis, constraining the numerical values of $B_{\max }$ or $K_{\mathrm{D}}$ frequently improves the resolution of binding data (Clark et al., 1989). Indeed, by keeping high-affinity antagonist binding in the absence and presence of $2 \mu \mathrm{M}$ ICI 174,864 at the set value of 180 fmol/mg of protein, the corresponding $K_{\mathrm{D}} \mathrm{S}$ were 0.3 $\mathrm{n} M$ (control) and $0.4 \mathrm{n} M$ (presence of displacer), indicating that with decreasing concentration of displacing ligand, the binding affinity of the nontargeted sites approaches that of the control (Fig. 3, inset). It should be mentioned that in the presence of $2 \mu M$ ICI 174,864, the equilibrium binding of the opioid agonist $\left[{ }^{3} \mathrm{H}\right]$ dihydromorphine retained its biphasic nature (A. E. Remmers and F. Medzihradsky, unpublished data).

\section{DISCUSSION}

We have recently described the reconstitution of high-affinity opioid-agonist binding in brain membranes (Remmers and Medzihradsky, 1991). After inactivation of $\mathrm{G}$ proteins by alkali treatment, the highaffinity, GTP-sensitive component of $\left[{ }^{3} \mathrm{H}\right]$ dihydromorphine was abolished. It was restored by fusing the synaptosomal membranes with membranes from opioid receptor-deficient but $\mathrm{G}$ protein-containing $\mathrm{C} 6$ glioma cells. In contrast to that of the agonist, $\left[{ }^{3} \mathrm{H}\right]$ naltrexone binding was not influenced by the elimination or readdition of $\mathrm{G}$ proteins. In the present study, performed in the presence of sodium to convert the receptor into the antagonist conformation, GTP$\gamma$-S had no effect on $\left[{ }^{3} \mathrm{H}\right]$ naltrexone binding. Rather, the results indicate that the biphasic binding of $\left[{ }^{3} \mathrm{H}\right]$ naltrexone in synaptosomal membranes from rat brain cortex reflects interactions with $\mu$-and $\delta$-opioid receptors. Highly selective $\mu$ - and $\delta$-opioid ligands 
preferentially inhibited and, at appropriate concentrations, eliminated the high- and low-affinity binding components, respectively, of $\left[{ }^{3} \mathrm{H}\right]$ naltrexone. These results are in line with the limited selectivity of $\left[{ }^{3} \mathrm{H}\right]$ naltrexone binding (Gillan et al., 1980) and with the heterogeneity of its dissociation from receptor (Fischel and Medzihradsky, 1981).

The displacement by $\mu$ and $\delta$ opioids accounted for both binding components of $\left[{ }^{3} \mathrm{H}\right]$ naltrexone. Attempts to also implicate the $\kappa$ receptors, by investigating the interactions of naltrexone and U69,593, were unsuccessful. Using quantitative autoradiography, the relative densities of $\mu, \delta$, and $\kappa$ receptors in the neocortex of rat brain were determined to be 42,59 , and $19 \%$, respectively (Tempel and Zukin, 1987). In that study, $\left[{ }^{3} \mathrm{H}\right]$ ethylketocyclazocine was used as a $k$-selective ligand together with DAMGO and [D-Ala $\left.{ }^{2}, \mathrm{D}-\mathrm{Leu}^{5}\right]-$ enkephalin (DADLE) to block binding to $\kappa$ and $\delta$ sites, respectively. Considering the marginal selectivity of DADLE as a $\delta$ opioid (James and Goldstein, 1984), the protection against $\left[{ }^{3} \mathrm{H}\right]$ ethylketocyclazocine binding to $\delta$ receptors might have been inadequate. As determined by binding of receptor-selective opioids, the density of $\kappa$ sites in rat brain comprised only $12 \%$ of the sum of $\mu-, \delta$, and $\kappa$-binding sites (Gillan and Kosterlitz, 1982). In our study, the presence of $\kappa$ sites not saturated by $20 \mathrm{n} M\left[{ }^{3} \mathrm{H}\right]$ naltrexone, or of $\kappa$ sites not specific for U69,593, was not investigated.

Optimal resolution of $\left[{ }^{3} \mathrm{H}\right]$ naltrexone binding, that is, the complete elimination of either of its two binding components was dependent on the use of the inhibitory ligands at an appropriate excess. Whereas in the presence of insufficient ligand biphasic binding was maintained, with rising concentrations the displacing opioid increasingly interacted with the other, nonselective receptor sites. It has been previously shown that biphasic Scatchard plots of nonselective opioids such as the $\delta /$ $\mu$ agonist DADLE became linear in the presence of selective ligands that blocked access to one of the available receptor populations (Gillan and Kosterlitz, 1982; Werling et al., 1985). A specific relationship between $\mu$ and $\delta$ sites existing on the same receptor complex has been proposed earlier by Rothman et al. (1985): the occupancy of the low-affinity $\delta$ sites noncompetitively inhibited ligand binding to the high-affinity $\mu$ sites. However, under the experimental conditions of that study (ammonium acetate buffer, $\mathrm{pH} 7.7,4^{\circ} \mathrm{C}$ ), $\left[{ }^{3} \mathrm{H}\right]$ naloxone bound to $\mu$ and $\kappa$ but not $\delta$ sites in rat brain membranes. On the other hand, high-affinity naloxone binding to $\delta$ receptors in brain membranes from rat and guinea pig at $25^{\circ} \mathrm{C}$ has convincingly been demonstrated (Gillan et al., 1980; James and Goldstein, 1984; Clark et al., 1988).

Together with the reconstitution of high-affinity agonist binding with $G$ protein (Remmers and Medzihradsky, 1991), the results presented here provide a molecular basis for the heterogeneity in the binding of opioid agonists and antagonists. The described reso- lution of $\left[{ }^{3} \mathrm{H}\right]$ naltrexone binding corroborates the conclusion reached in a recently completed study on the modulation of opioid receptors in brain membranes by fatty acids (Remmers et al., 1990). These compounds preferentially inhibited the binding of $\delta$-selective agonists and the low-affinity binding component of $\left.{ }^{3} \mathrm{H}\right]$ naltrexone. The results of the present study support the view that the effect of the fatty acids reflects the targeting of the $\delta$ receptor localized in a cationic membrane environment (Schwyzer, 1986). Notwithstanding the now accomplished characterization of opioid-ligand binding, additional studies are needed to clarify the different binding properties (biphasic and monophasic binding components, respectively) of opioid alkaloids and peptides of identical receptor selectivity (e.g., Ward et al., 1986).

Acknowledgment: We are grateful to Dr. G. Nordby for his advice on data analysis, and would like to thank Ms. $R$. McLaughlin for expert secretarial assistance. This work was supported by USPHS grant DA 04087.

\section{REFERENCES}

Blume A. J. (1978) Interaction of ligands with the opiate receptors of brain membranes: regulation by ions and nucleotides. Proc. Natl. Acad. Sci. USA 75, 1713-1717.

Bradford M. M. (1976) A rapid and sensitive method for the quantitation of microgram quantities of protein utilizing the principle of protein-dye binding. Anal. Biochem. 72, 248-254.

Cahill A. L. and Medzihradsky F. (1976) Interaction of central nervous system drugs with synaptosomal transport processes. Biochem. Pharmacol. 25, 2257-2264.

Childers S. R. and Snyder S. H. (1980) Differential regulation by guanine nucleotides of opiate agonist and antagonist receptor interactions. J. Neurochem. 34, 583-593.

Clark M. J., Carter B. D., and Medzihradsky F. (1988) Selectivity of ligand binding to opioid receptors in brain membranes from the rat, monkey, and guinea pig. Eur. J. Pharmacol. 148, 343-351.

Clark M. J., Nordby G. L., and Medzihradsky F. (1989) Relationship between opioid receptor occupancy and stimulation of low-Km GTPase in brain membranes. J. Neurochem. 52, 1162-1169.

Fischel S. V. and Medzihradsky F. (1981) Scatchard analysis of opiate receptor binding. Mol. Pharmacol. 20, 269-279.

Fischel S. V. and Medzihradsky F. (1986) Interaction between $\left[{ }^{3} \mathrm{H}\right]$ ethylketocyclazocine and etorphine and opioid receptors in membranes from rat brain. A kinetic analysis. Neuropharmacology 25, 351-359.

Gillan M. G. C. and Kosterlitz H. W. (1982) Spectrum of the $\mu$-, $\delta$-, and $x$-binding sites in homogenates of rat brain. Eur. J. Pharmacol. 77, 461-469.

Gillan M. G. C., Kosterlitz H. W., and Patterson S. J. (1980) Comparison of the binding characteristics of tritiated opiates and opioid peptides. Br. J. Pharmacol. 70, 481-490.

James I. and Goldstein A. (1984) Site-directed alkylation of multiple opioid receptors. I. Binding selectivity. Mol. Pharmacol. 25, 337342 .

Leysen J. E., Gommers W., and Niemegeers C. G. E. (1983) $\left[{ }^{3} \mathrm{H}\right]$ Sufentanil, a superior ligand for $\mu$-opiate receptors: binding properties and regional distribution in rat brain and spinal cord. Eur. J. Pharmacol. 87, 209-225.

Remmers A. E. and Medzihradsky F. (1991) Reconstitution of highaffinity opioid agonist binding in brain membranes. Proc. Natl. Acad. Sci. USA 88, 2171-2175.

Remmers A. E., Nordby G. L., and Medzihradsky F. (1990) Mod- 
ulation of opioid receptor binding by cis and trans fatty acids. J. Neurochem. 55, 1993-2000.

Rothman R. B., Danks J. A., Jacobson A. E., and Rice K. C. (1985) Leucine enkephalin noncompetitively inhibits the binding of $\left[{ }^{3} \mathrm{H}\right]$ naloxone to the opiate $\mu$-recognition site: evidence for $\delta-\mu$ binding site interactions in vitro. Neuropeptides 6, 351-363.

Schwyzer R. (1986) Molecular mechanisms of opioid receptor selection. Biochemistry 25, 6335-6342.

Szücs M., Borsodi A., Bogdany A., Gaal J., Batke J., and Toth G. (1987) Detailed analysis of heterogeneity of $\left[{ }^{3} \mathrm{H}\right]$ naloxone binding sites in rat brain synaptosomes. Neurochem. Res. 12, 581-587.

Tempel A. and Zukin R. S. (1987) Neuroanatomical patterns of $\mu$, $\delta$, and $\kappa$ opioid receptors in rat brain as determined by quanti- tative in vitro autoradiography. Proc. Natl. Acad. Sci. USA 84, $4308-4312$.

Ward S. J., LoPresti D., and James D. W. (1986) Activity of the $\mu$ and $\delta$-selective agonists in the guinea pig ileum preparation: differentiation into peptide and nonpeptide classes with $\beta$-funaltrexamine. J. Pharmacol. Exp. Ther. 238, 625-631.

Werling L. L., Zarr G., Brown S. R., and Cox B. M. (1985) Opioid binding to rat and guinea-pig neural membranes in the presence of physiological cations at $37^{\circ} \mathrm{C}$. Mol. Pharmacol. 88, 423-431.

Woods J. H., DeCosta B., Jacobson A. E., Rice K. C., Medzihradsky F., Smith C. B., Comer S., France C. P., and Winger G. (1990) $\delta$ Opioid receptor selective alkaloid agonists and antagonists. Res. Monogr. Natl. Inst. Drug Abuse 95, 300-301. 